\title{
ANALISA KEKOKOHAN TANGGAPAN TEGANGAN SISTEM EKSITASI GENERATOR TIPE ARUS SEARAH DENGAN BERBAGAI PENGENDALI
}

\author{
Heru Dibyo Laksono ${ }^{(1)}$, Doohan Haliman ${ }^{(2)}$, Aidil Danas ${ }^{(3)}$, Wayu Diafridho A $^{(4)}$ \\ $(1,2)$ Jurusan Teknik Elektro Fakultas Teknik Universitas Andalas \\ (3) Jurusan Teknik Elektro Fakultas Teknik Universitas Eka Sakti \\ ${ }^{(4)}$ PT. PLN (Persero) Area Padang Sidempuan Sumatera Utara \\ Email : heru_dl@ft.unand.ac.id
}

\begin{abstract}
Abstrak - Kekokohan tanggapan tegangan sistem eksitasi generator merupakan kemampuan dari sistem eksitasi generator untuk meredam derau pada frekuensi tinggi, mempuyai tanggapan yang cepat terhadap masukan tertentu dan mampu menghilangkan gangguan pada saat beroperasi. Pada jurnal ini dilakukan pembahasan tentang analisa kekokohan tanggapan tegangan sistem eksitasi generator dengan berbagai pengendali. Dengan menggunakan nilai kriteria puncak maksimum dan kriteria margin penguatan dan margin fasa dilakukan analisa kekokohan pada tanggapan tegangan sistem eksitasi generator. Kriteria nilai puncak maksimum ini terbagi atas 2 bahagian yaitu nilai kriteria puncak maksimum sensitivitas dan nilai kriteria puncak maksimum sensitivitas komplementer. Untuk jenis - jenis pengendali yang digunakan terdiri dari pengendali Proporsional (P), pengendali Proporsional Integral (PI), pengendali Proporsional Diferensial (PD), pengendali Proporsional Integral Diferensial (PID), pengendali Proporsional Diferensial dengan filter orde pertama pada bagian diferensial (PDF) dan pengendali Proporsional Integral Diferensial dengan filter orde pertama pada bagian diferensial (PIDF). Hasil yang diperoleh bahwa tanggapan tegangan sistem eksitasi generator dengan pengendali Proporsional (P), pengendali Proporsional Integral (PI), pengendali Proporsional Diferensial (PD), pengendali Proporsional Integral Diferensial (PID), pengendali Proporsional Diferensial dengan filter orde pertama pada bagian diferensial (PDF) dan pengendali Proporsional Integral Diferensial Dengan Filter Orde Pertama (PIDF) bersifat kokoh terhadap gangguan, mampu meredam derau pada frekuensi tinggi dan mempuyai tanggapan yang cepat terhadap masukan tertentu. Hal ini dibuktikan dengan nilai puncak sensitivitas yang kecil dari 2.0000 dan nilai puncak sensitivitas komplementer yang kecil dari 1.2500, batasan minimum dari margin penguatan besar dari $6.0000 \mathrm{~dB}$ dan batasan minimum dari margin fasa antara 30.0000 derjat s/d 60.0000 derjat untuk setiap pengendali.
\end{abstract}

Kata kunci : kekokohan, sistem eksitasi, puncak maksimum sensitivitas, puncak maksimum sentivitas komplementer, margin penguatan, margin fasa.

\begin{abstract}
The voltage response robustness of generator excitation system is the ability of generator excitation system to muffle noise at high frequency, has rapid response to specific input and is able to eliminate disturbance during operation. In this journal is conducted a discussion about the voltage response robustness analysis of generator excitation system with various controllers. By using the criteria of the maximum peak value, phase margin and gain margin are analyzed the voltage response robustness of generator excitation. The criteria of maximum peak value is divided into two specifically the criteria of the sensitivity maximum peak value and the criteria of the complementary sensitivity maximum peak value. The type of controllers are designed include Proportional controller (P), Proportional Integral controller (PI), Proportional Differential controller (PD), Proportional Integral Differential controller (PID), Proportional Differential controller with First Order Filter In Part Differential (PDF) and Proportional Integral Differential controller with First Order Filter in Part Differential (PIDF). The results showed that the voltage response of generator excitation system with Proportional controller (P), Proportional Integral controller (PI), Proportional Differential controller (PD), Proportional Integral Differential controller (PID) Proportional Differential controller with First Order Filter In Part Differential (PDF) and Proportional Integral Differential controller with First Order Filter in Part Differential (PIDF) is robust to disturbance, able to reduce noise at high frequencies and having rapid response to specific input. This is evidenced by sensitivity peak value smaller than 2.0000 and complementary sensitivity peak value smaller than 1.2500 , the minimum limit of gain margin greater than $6.0000 \mathrm{~dB}$ and the minimum limit of phase margin between 30.0000 degrees to 60.0000 degrees for each controller.
\end{abstract}


Keyword: robustness, excitation system, sensitivity maximum peak, complementary sensitivity maximum peak, gain margin, phase margin.

\section{PENDAHULUAN}

Besarnya arus eksitasi pada sistem kendali generator mempengaruhi besarnya tegangan keluaran generator. Besarnya tegangan keluaran ini mempengaruhi besarnya energi listrik yang dihasilkan. Besarnya atau kecil energi listrik yang dihasilkan oleh generator ini dipengaruhi juga sistem pasokan listrik arus searah [1]. Kemampuan dari sistem eksitasi generator untuk meredam derau pada frekuensi tinggi, mempuyai tanggapan yang cepat terhadap masukan tertentu dan mampu menghilangkan gangguan pada saat beroperasi dikenal sebagai analisa kekokohan [2]. Pada analisa kekokohan ini akan diamati tingkat kekokohan tanggapan tegangan sistem eksitasi generator tanpa dan dengan pengendali. Sistem eksitasi adalah suatu peralatan yang berguna untuk menjaga performansi tegangan dan daya reaktif generator agar tetap pada nilai operasi yang diinginkan. Pertambahan daya reaktif pada sisi beban akan menyebabkan penurunan magnitude tegangan terminal. Penurunan tegangan terminal ini kemudian akan disensor oleh suatu potensial transformator. Selanjutnya tegangan terminal akan disearahkan dan dibandingkan dengan suatu titik nilai acuan [1],[3].

Pengatur sinyal kesalahan penguat akan mengatur tegangan eksitasi sehingga tegangan eksitasi generator akan meningkat. Jika tegangan eksitasi meningkat maka daya tegangan yang dibangkitkan oleh generator akan meningkat pula. Sistem eksitasi generator merupakan elemen penting untuk membentuk profil tegangan terminal generator yang stabil. Sistem pengoperasian unit eksitasi generator ini berfungsi untuk menjaga agar tegangan generator tetap konstan dengan kata lain generator akan tetap mengeluarkan tegangan yang selalu stabil tidak terpengaruh pada perubahan beban yang selalu berubah-ubah, dikarenakan beban sangat mempengaruhi tegangan keluaran generator [3].

Beberapa penelitian yang sudah dilakukan diantaranya [4], pada jurnal ini dibahas pemodelan dan analisa sistem eksitasi generator. Model sistem eksitasi yang dibahas meliputi sistem eksitasi generator tipe arus searah, model sistem eksitasi generator tipe arus searah dengan
Rate Output Feedback, model sistem eksitasi generator tipe arus searah dengan Transient Gain Reduction dan model sistem eksitasi generator tipe statik. Hasil analisa memperlihatkan bahwa sistem eksitasi generator tipe arus searah dengan Rate Output Feedback memiliki performansi, kestabilan dan kekokohan yang lebih baik dibandingkan dengan sistem eksitasi generator tipe arus searah, sistem eksitasi generator tipe arus searah dengan Transient Gain Reduction dan sistem eksitasi generator tipe statik.[5], pembahasan pada jurnal ini meliputi perancangan dan analisa kendali sistem eksitasi generator tipe arus searah dengan PIDTool model paralel. Hasil analisa memperlihatkan bahwa sistem kendali eksitasi generator tipe arus searah dengan pengendali Proporsional Diferensial dengan Filter Orde Pertama Pada Bagian Diferensial (PDF) memenuhi kriteria kekokohan yang diinginkan. [6], membahas evaluasi kekokohan tangapan tegangan sistem eksitasi generator dengan metoda penempatan kutub menggunakan algoritma Bass - Gura. Adapun informasi yang diperoleh, bahwa kekokohan tanggapan tegangan sistem eksitasi generator dengan metoda penempatan kutub menunjukkan kekokohan yang lebih baik dibandingkan kekokohan tangapaan tegangan sistem eksitasi tanpa metoda penempatan kutub. [7], membahas evaluasi kestabilan dan kekokohan tanggapan tegangan sistem eksitasi generator dengan metoda penempatan kutub menggunakan algoritma Ackerman dan diperoleh informasi bahwa kestabilan dan kekokohan tanggapan tegangan sistem eksitasi generator menunjukkan performansi kestabilan dan kekokohan yang lebih baik dibandingkan performansi kestabilan dan kekokohan tanggapan tegangan sistem eksitasi tanpa metoda penempatan kutub. [8], pada jurnal ini membahas tentang analisa tanggapan tegangan sistem eksitasi generator dengan metoda $\mathrm{H} \sim$. Informasi yang diperoleh bahwa tanggapan tegangan sistem eksitasi mempuyai performansi, kestabilan dan kekokohan yang lebih baik dibandingkan dengan sistem eksitasi tanpa metoda $\mathrm{H} \sim$. [9], membahas analisa peralihan sistem kendali eksitasi generator konvensional dan non konvensional. 
Selain itu untuk beberapa penelitian yang sudah dilakukan [5-9] dimana kekokohan tanggapan tegangan sistem eksitasi generator dilakukan menggunakan kriteria nilai puncak maksimum. Kriteria nilai puncak maksimum ini terdiri atas 2 bahagian yaitu nilai puncak maksimum sensitivitas dan nilai puncak maksimum sensitivitas komplementer. Untuk analisa kekokohan, selain dilakukan dengan kriteria nilai puncak maksimum juga dilakukan kriteria margin penguatan dan margin fasa. Hasil penelitian menunjukkan bahwa tanggapan tegangan sistem eksitasi generator bersifat kokoh tetapi informasi kriteria margin penguatan dan margin fasa dari tanggapan tegangan sistem eksitasi ini tidak diperoleh. Untuk itu dengan menggunakan bantuan perangkat lunak Matlab dilakukan analisa kekokohan tanggapan tanggapan tegangan sistem eksitasi generator dengan menggunakan nilai kriteria puncak maksimum, kriteria margin penguatan dan margin fasa. Analisa kekokohan tanggapan tegangan sistem eksitasi ini dilakukan tanpa dan dengan menggunakan berbagai pengendali. Adapun jenis pengendali yang digunakan pengendali Proporsional (P), pengendali Proporsional Integral (PI), pengendali Proporsional Diferensial (PD), pengendali Proporsional Integral Diferensial (PID), pengendali Proporsional Diferensial dengan filter orde pertama pada bagian diferensial (PDF) dan pengendali Proporsional Integral Diferensial dengan filter orde pertama pada bagian diferensial (PIDF).

Dengan adanya penelitian ini diharapkan nantinya diperoleh informasi kekokohan tanggapan tegangan sistem eksitasi generator terhadap gangguan, mampu meredam derau pada frekuensi tinggi dan mempuyai tanggapan yang cepat terhadap masukan tertentu. Agar tercapai hasil penelitian yang diinginkan maka penelitian ini dibatasi sebagai berikut :

1. Model sistem eksitasi generator bersifat linier, tak berubah terhadap waktu dan kontinu.

2. Sistem eksitasi generator bersifat satu masukan dan satu keluaran

3. Analisa dilakukan dengan bantuan perangkat lunak Matlab

\section{TINJAUAN PUSTAKA}

Pada bagian ini dibahas tentang pemodelan sistem eksitasi generator, pengendali dan analisa kekokohan. Untuk pemodelan matematis sistem eksitasi generator meliputi pemodelan amplifier, pemodelan eksiter dan pemodelan generator. Untuk pemodelan matematis amplifier dinyatakan dalam bentuk persamaan (1) berikut[10] :

$$
\frac{\mathrm{V}_{\mathrm{R}}(\mathrm{s})}{\mathrm{V}_{\mathrm{E}}(\mathrm{s})}=\frac{\mathrm{K}_{\mathrm{A}}}{1+\tau_{\mathrm{A}} \mathrm{s}}
$$

Hasil pemodelan matematis amplifier berupa fungsi alih orde satu dengan 2 parameter yaitu konstanta penguatan amplifier dan konstanta waktu amplifier. Nilai konstanta penguatan amplifier memiliki rentang nilai dari 10.0000 sampai 400.000 sedangkan nilai konstanta waktu amplifier memiliki rentang nilai dari 0.0200 detik sampai 0.1000 detik. Untuk pemodelan matematis eksiter dinyatakan dalam bentuk persamaan (2) berikut [10] :

$$
\frac{\mathrm{V}_{\mathrm{F}}(\mathrm{s})}{\mathrm{V}_{\mathrm{R}}(\mathrm{s})}=\frac{\mathrm{K}_{\mathrm{E}}}{1+\tau_{\mathrm{E}} \mathrm{s}}
$$

Hasil pemodelan matematis eksiter ini berupa fungsi alih orde satu dengan 2 parameter yaitu konstanta penguatan eksiter dan konstanta waktu eksiter. Untuk konstanta penguatan eksiter dan konstanta waktu eksiter ini mempuyai nilai yang kecil. Untuk pemodelan matematis generator dinyatakan dalam bentuk persamaan (3) berikut [10] :

$$
\frac{\mathrm{V}_{\mathrm{T}}(\mathrm{s})}{\mathrm{V}_{\mathrm{F}}(\mathrm{s})}=\frac{\mathrm{K}_{\mathrm{G}}}{1+\tau_{\mathrm{G}} \mathrm{s}}
$$

Hasil pemodelan matematis generator ini berupa fungsi alih orde satu dengan 2 parameter yaitu konstanta penguatan generator dan konstanta waktu generator. Nilai konstanta penguatan generator memiliki rentang nilai dari 0.7000 sampai 1.0000 sedangkan nilai konstanta waktu generator memiliki nilai rentang nilai dari 1.0000 detik sampai 2.0000 detik pada keadaan beban nol sampai keadaan beban penuh. Selanjutnya komponen - komponen sistem eksitasi generator ini digabungkan dan terbentuk 
diagram blok dari sistem eksitasi generator yang diperlihatkan pada Gambar 1. Berdasarkan diagram blok pada Gambar 1. kemudian diperoleh fungsi alih lingkar terbuka dan fungsi alih lingkar tertutup dari sistem eksitasi generator. Untuk fungsi alih lingkar terbuka diperlihatkan pada persamaan (4) dan fungsi alih lingkar tertutup diperlihatkan pada persamaan (5). Pengendali yang digunakan diantaranya pengendali Proporsional (P), pengendali Proporsional Integral (PI), pengendali Proporsional Diferensial (PD), pengendali Proporsional Integral Diferensial (PID), pengendali Proporsional Diferensial dengan filter orde pertama pada bagian diferensial (PDF) dan pengendali Proporsional Integral Diferensial dengan filter orde pertama pada bagian diferensial (PIDF). Pengendali pengendali tersebut dirancang dengan menggunakan PIDTool Matlab model standard. Untuk fungsi pengendali Proporsional (P) diperlihatkan pada persamaan (4) berikut [11][12] :

$$
\mathrm{C}(\mathrm{s})=\mathrm{K}_{\mathrm{p}}
$$

Untuk fungsi alih pengendali Proporsional Integral (PI) diperlihatkan pada persamaan (5) berikut [11][12] :

$$
\mathrm{C}(\mathrm{s})=\mathrm{K}_{\mathrm{p}}\left(1+\frac{1}{\mathrm{~T}_{\mathrm{i}} \mathrm{s}}\right)
$$

Fungsi alih pengendali Proporsional Diferensial (PD) diperlihatkan pada persamaan (6) berikut [11][12] :

$$
\mathrm{C}(\mathrm{s})=\mathrm{K}_{\mathrm{p}}\left(1+\mathrm{T}_{\mathrm{d}} \mathrm{s}\right)
$$

Fungsi alih pengendali Proporsional Integral Diferensial (PID) diperlihatkan pada persamaan (7) berikut [11][12] :

$$
\mathrm{C}(\mathrm{s})=\mathrm{K}_{\mathrm{p}}\left(1+\frac{1}{\mathrm{~T}_{\mathrm{i}} \mathrm{s}}+\mathrm{T}_{\mathrm{d}} \mathrm{s}\right)
$$

Fungsi alih pengendali Proporsional Diferensial dengan filter orde pertama pada bagian diferensial (PDF) diperlihatkan pada persamaan (8) berikut [11][12] :

$$
C(s)=K_{p}\left(1+\frac{T_{d} s}{\frac{T_{d}}{N} s+1}\right)
$$

Fungsi alih pengendali Proporsional Integral Diferensial Dengan Filter Orde Pertama Pada Bagian Diferensial (PIDF) diperlihatkan pada persamaan (9) berikut : [11][12]

$$
C(s)=K_{p}\left(1+\frac{1}{T_{i} s}+\frac{T_{d} s}{\frac{T_{d}}{N} s+1}\right)
$$

Untuk fungsi alih lingkar terbuka dinyatakan dengan persamaan (10) berikut:

$$
G(s) H(s)=\frac{K_{A} K_{E} K_{G}}{\left(1+T_{A} s\right)\left(1+T_{E} s\right)\left(1+T_{G} s\right)}
$$

Untuk fungsi alih lingkar tertutup dinyatakan dengan persamaan (11) berikut

$$
\frac{V_{t}(s)}{V_{\text {ref }}(s)}=\frac{K_{A} K_{E} K_{G}}{\left(1+T_{A} s\right)\left(1+T_{E} s\right)\left(1+T_{G} s\right)+K_{A} K_{E} K_{G}}
$$

Jika diagram blok pada Gambar 1. dan Gambar 2. dibandingkan maka diperoleh persamaan (12) berikut :

$$
G(s)=\frac{K_{A} K_{E} K_{G}}{\left(1+T_{A} s\right)\left(1+T_{E} s\right)\left(1+T_{G} s\right)}
$$

dan $\mathrm{C}(\mathrm{s})$ merupakan fungsi alih pengendali digunakan. Selain itu dengan mensubstitusi nilai - nilai pada Tabel 1. ke persamaan (10) dan (11) maka diperoleh persamaan (13) dan (14) berikut:

$\mathrm{G}(\mathrm{s}) \mathrm{H}(\mathrm{s})=\frac{16.0000}{0.0180 \mathrm{~s}^{3}+0.4020 \mathrm{~s}^{2}+1.7600 \mathrm{~s}+1.0000}$

$\frac{\mathrm{V}_{\mathrm{t}}(\mathrm{s})}{\mathrm{V}_{\text {ref }}(\mathrm{s})}=\frac{16.0000}{0.0180 \mathrm{~s}^{3}+0.4020 \mathrm{~s}^{2}+1.7600 \mathrm{~s}+17.0000}$

Untuk analisa kekokohan dilakukan dengan menggunakan kriteria nilai puncak maksimum. Kriteria puncak maksimum ini terbagi atas 2 bahagian yaitu nilai puncak maksimum 
sensitivitas dan nilai puncak maksimum sensitivitas komplementer $\left(\mathrm{M}_{\mathrm{s}}\right)$, kriteria margin penguatan dan margin fasa [2][11]. Untuk nilai puncak maksimum sensitivitas dihitung dengan persamaan (15) berikut :

$$
M_{s}=\max _{\omega}|S(j \omega)|
$$

Untuk nilai puncak maksimum sensitivitas komplementer $\left(\mathrm{M}_{\mathrm{t}}\right)$ ini dihitung dengan persamaan (16) berikut :

$$
\mathrm{M}_{\mathrm{T}}=\max _{\omega}|\mathrm{T}(\mathrm{j} \omega)|
$$

Dimana S(s) adalah fungsi alih sensitivitas dan $\mathrm{T}(\mathrm{s})$ adalah fungsi alih sensitivitas komplementer. Untuk fungsi alih sensitivitas dinyatakan dengan persamaan (17) berikut :

$$
\mathrm{S}(\mathrm{s})=\frac{1}{1+\mathrm{L}(\mathrm{s})}
$$

Fungsi alih sensitivitas komplementer dinyatakan dengan persamaan (18) berikut :

$$
\mathrm{T}(\mathrm{s})=\frac{\mathrm{L}(\mathrm{s})}{1+\mathrm{L}(\mathrm{s})}=1-\mathrm{S}(\mathrm{s})
$$

dimana

$$
\mathrm{L}(\mathrm{s})=\mathrm{G}(\mathrm{s}) \mathrm{K}(\mathrm{s})
$$

Persamaan (15) s/d (19) ini diperoleh berdasarkan dari diagram blok pada Gambar 3 .
Untuk sistem yang bersifat kokoh, nilai puncak maksimum sensitivitas kurang dari $2(6 \mathrm{~dB})$ dan nilai puncak maksimum sensitivitas komplementer kurang dari $1.25 \quad(2 \mathrm{~dB})$ (Skogestad \& Postlethwaite, 1996). Jika nilai puncak maksimum sensitivitas dan nilai puncak maksimum sensitivitas komplementer bertambah besar maka performansi sistem dalam domain frekuensi dan kekokohan sistem akan semakin jelek. Hubungan antara kriteria puncak maksimum dengan margin penguatan dan margin phasa dinyatakan dengan persamaan (20) s/d (21). Jika diketahui nilai $\mathrm{M}_{\mathrm{s}}$ maka hubungannya dinyatakan oleh persamaan (14) dan (15) berikut :

$$
\mathrm{GM} \geq \frac{\mathrm{M}_{\mathrm{s}}}{\mathrm{M}_{\mathrm{s}}-1}
$$

$$
\mathrm{PM} \geq 2 \sin ^{-1}\left(\frac{1}{2 \mathrm{M}_{\mathrm{s}}}\right) \geq \frac{1}{\mathrm{M}_{\mathrm{s}}} \text { radian }
$$

Jika diketahui nilai $\mathrm{M}_{\mathrm{T}}$ maka hubungannya dinyatakan oleh persamaan (22) dan (23) berikut :

$$
\mathrm{GM} \geq 1+\frac{1}{\mathrm{M}_{\mathrm{T}}}
$$

$$
\mathrm{PM} \geq 2 \sin ^{-1}\left(\frac{1}{2 \mathrm{M}_{\mathrm{s}}}\right) \geq \frac{1}{\mathrm{M}_{\mathrm{s}}} \text { radian }
$$

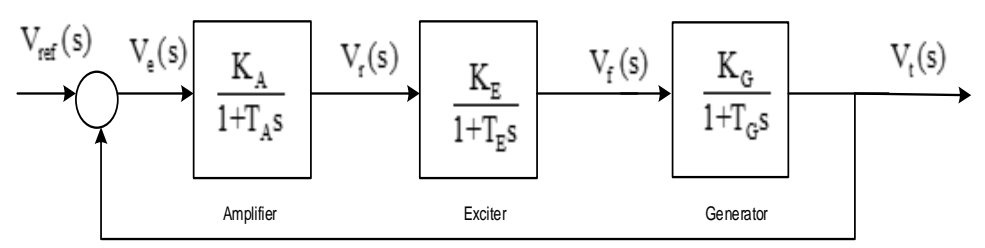

Gambar 1. Diagram Blok Sistem Eksitasi Generator Tipe Arus Searah [10][11] 


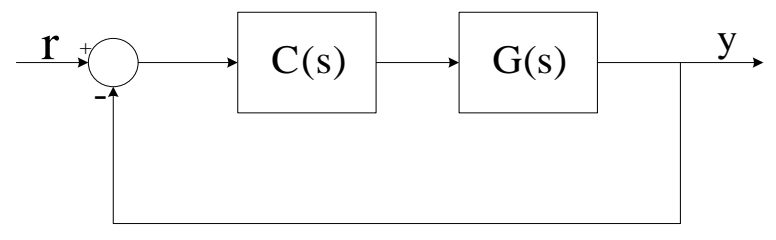

Gambar 2. Diagram Blok Sistem Eksitasi Generator

Tipe Arus Searah Dengan Pengendali [10][[11]

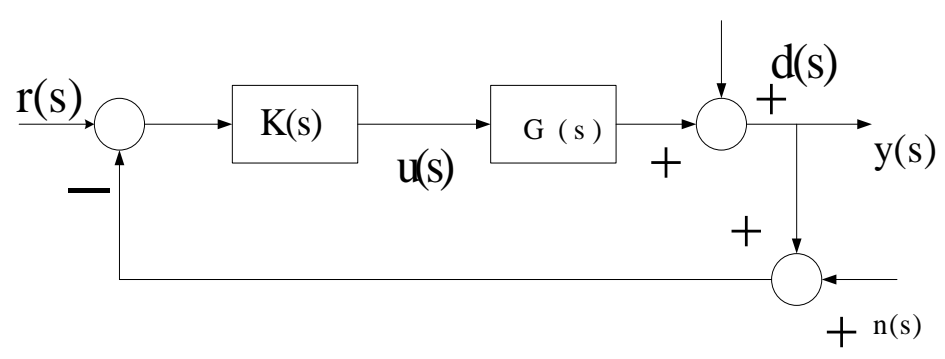

Gambar 3. Diagram Blok Sistem Umpan Balik Multivariabel [2]

Tabel 1. Keterangan Parameter Sistem Ekstiasi Generator

\begin{tabular}{|c|l|}
\hline Parameter & \multicolumn{1}{c|}{ Keterangan } \\
\hline $\mathrm{K}_{\mathrm{A}}$ & Konstanta penguatan amplifier \\
\hline $\mathrm{T}_{\mathrm{A}}$ & Konstanta waktu amplifier \\
\hline $\mathrm{K}_{\mathrm{E}}$ & Konstanta penguatan eksiter \\
\hline $\mathrm{T}_{\mathrm{E}}$ & Konstanta waktu eksiter \\
\hline $\mathrm{K}_{\mathrm{G}}$ & Konstanta penguatan generator \\
\hline $\mathrm{T}_{\mathrm{G}}$ & Konstanta waktu generator \\
\hline $\mathrm{K}_{\mathrm{p}}$ & Konstana proporsinal dimana nilainya real \\
\hline $\mathrm{T}_{\mathrm{i}}$ & $\begin{array}{l}\text { Konstanta waktu integral dimana } \\
\text { nilainya real dan besar atau sama dengan } \\
\text { nol }\end{array}$ \\
\hline $\mathrm{T}_{\mathrm{d}}$ & $\begin{array}{l}\text { konstanta waktu diferensial dimana nilainya } \\
\text { real dan besar atau sama dengan nol }\end{array}$ \\
\hline $\mathrm{N}$ & $\begin{array}{l}\text { konstanta waktu diferensial untuk filter orde } \\
\text { satu dimana nilainya real dan besar atau sama } \\
\text { dengan nol }\end{array}$ \\
\hline
\end{tabular}

\section{METODE PENELITIAN}

Pada bagian ini terdiri dari metodologi penelitian dan data - data parameter sistem eksitasi generator.

\subsection{Metodologi Penelitian}

Penelitian ini dimulai dengan pemodelan matematis sistem eksitasi generator. Pemodelan matematis sistem eksitasi generator yang dibahas meliputi pemodelan amplifier, pemodelan eksiter dan pemodelan generator. Tipe sistem eksitasi generator yang digunakan adalah sistem eksitasi generator tipe arus searah dengan umpan balik satu dengan bentuk diagram blok yang diperlihatkan pada Gambar 1. Selain itu pemodelan matematis sistem eksitasi generator ini dilakukan dengan menggunakan 
persamaan linear diferensial dan transformasi Laplace. Hasil pemodelan dari masing - masing komponen ini berupa fungsi alih orde satu. Masing - masing komponen ini digabungkan dan diperoleh fungsi alih lingkar terbuka dan fungsi alih lingkar tertutup dari sistem eksitasi generator. Untuk fungsi alih lingkar terbuka diperlihatkan pada persamaan (10) dan untuk fungsi alih lingkar tertutup diperlihatkan pada persamaan (11). Adapun keluaran dari kedua fungsi alih tersebut adalah tegangan terminal sedangkan masukannya adalah tegangan referensi. Nilai - nilai parameter dari sistem eksitasi generator pada Tabel 1. Kemudian disubstitusikan ke persamaan (10) dan (11) serta diperoleh persamaan (13) dan (14). Selanjutnya dilakukan analisa kekokohan dari tanggapan tegangan dari sistem eksitasi. Analisa kekokohan dilakukan dengan menggunakan kriteria nilai puncak maksimum. Kriteria puncak maksimum ini terbagi atas 2 bahagian yaitu nilai puncak maksimum sensitivitas dan nilai puncak maksimum sensitivitas komplementer. Selain itu berdasarkan nilai puncak maksimum sensitivitas dan nilai puncak maksimum sensitivitas komplementer ini juga dihitung batasan minimum margin penguatan dan batasan minimum margin fasa agar tanggapan tegangan sistem eksitasi ini bersifat kokoh terhadap gangguan, mampu meredam derau pada frekuensi tinggi dan mempuyai tanggapan yang cepat terhadap masukan tertentu.

Selanjutnya dilakukan perancangan pengendali untuk sistem eksitasi generator arus searah. Perancangan pengendali dilakukan dengan bantuan PIDTool Matlab Model Standard dan dengan menggunakan persamaan (10). Pengendali yang dirancang meliputi pengendali Proporsional (P), pengendali Proporsional Integral (PI), pengendali Proporsional Diferensial (PD), pengendali Proporsional Integral Diferensial (PID), pengendali Proporsional Diferensial dengan filter orde pertama pada bagian diferensial (PDF) dan pengendali Proporsional Integral Diferensial Dengan Filter Orde Pertama (PIDF). Hasil dari perancangan pengendali ini diperolehnya fungsi alih masing - masing pengendali. Adapun bentuk fungsi alih dari masing - masing pengendali diperlihatkan pada persamaan (4) s/d (9). Selanjutnya dengan berpedoman diagram blok pada Gambar 2 . maka diperoleh fungsi alih lingkar terbuka dan fungsi alih lingkar tertutup tanggapan tegangan sistem eksitasi generator dengan pengendali. Selanjutnya dilakukan analisa kekokohan tanggapan tegangan sistem eksitasi generator terhadap dengan pengendali. Analisa kekokohan yang dilakukan sama dengan analisa kekokohan tanggapan tegangan sistem eksitasi generator tanpa pengendali.

\subsection{Data - Data Parameter Sistem Eksitasi Generator}

Adapun parameter-parameter sistem eksitasi generator yang digunakan dalam penelitian ini diperlihatkan pada Tabel 2 . Berikut [10] :

Tabel 2. Nilai Parameter Sistem Eksitasi Generator [10]

\begin{tabular}{|c|c|}
\hline Parameter & Nilai \\
\hline $\mathrm{K}_{\mathrm{A}}$ & 20.0000 \\
\hline $\mathrm{T}_{\mathrm{A}}$ & 0.0600 \\
\hline $\mathrm{K}_{\mathrm{E}}$ & 1.0000 \\
\hline $\mathrm{T}_{\mathrm{E}}$ & 0.2000 \\
\hline $\mathrm{K}_{\mathrm{G}}$ & 0.8000 \\
\hline $\mathrm{T}_{\mathrm{G}}$ & 1.5000 \\
\hline
\end{tabular}

\section{HASIL DAN PEMBAHASAN}

Pada bagian ini dilakukan analisa kekokohan tanggapan tegangan sistem eksitasi generator tanpa dan dengan pengendali. Untuk hasil simulasi tanggapan tegangan sistem eksitasi generator tanpa pengendali diperoleh nilai puncak maksimum, nilai margin penguatan dan nilai margin fasa. Untuk nilai puncak maksimum terdiri dari nilai puncak maksimum sensitivitas dan nilai puncak maksimum sensitivitas komplementer. Adapun kedua nilai puncak maksimum ini diperlihatkan pada Tabel 2 . Berikut :

Tabel 3. Nilai Puncak Maksimum

\begin{tabular}{|l|c|}
\hline \multicolumn{1}{|c|}{ Parameter } & Nilai \\
\hline Nilai Pucak Sensitivitas & 2.9367 \\
\hline $\begin{array}{l}\text { Nilai Pucak Sensitivitas } \\
\text { Komplementer }\end{array}$ & 2.4776 \\
\hline
\end{tabular}


Grafik tanggapan fungsi sensitivitas dan fungsi sensitivitas komplementer dari tanggapan tegangan sistem eksitasi generator tanpa pengendali diperlihatkan pada Gambar 2. Berikut :

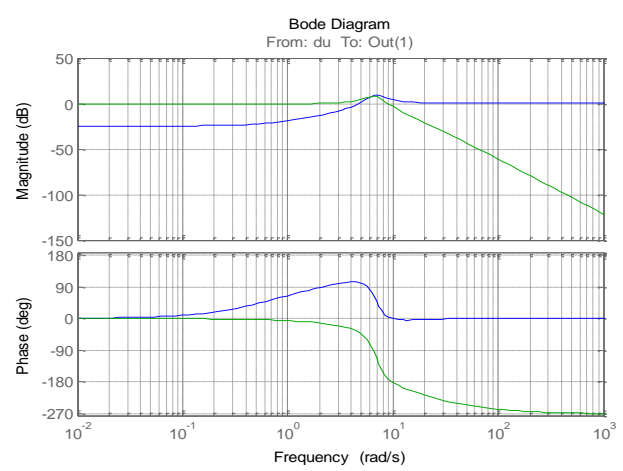

Gambar 4. Tanggapan Fungsi Sensitivitas dan Sensitivitas Komplemeneter

Berdasarkan nilai puncak maksimum ini diperoleh nilai margin penguatan dan nilai margin fasa dari tanggapan tegangan sistem eksitasi generator tanpa pengendali diperlihatkan pada Tabel 3. Berikut :

Tabel 4. Nilai Margin Penguatan dan Margin Fasa

\begin{tabular}{|l|c|}
\hline \multicolumn{1}{|c|}{ Parameter } & Nilai \\
\hline \multirow{2}{*}{ Margin Penguatan } & 1.5164 \\
\cline { 2 - 2 } & $3.6160 \mathrm{~dB}$ \\
\hline Margin Fasa & 19.6061 derjat \\
\hline
\end{tabular}

Berdasarkan hasil simulasi yang diperlihatkan pada Tabel 2. Dan Tabel 3. terlihat bahwa tanggapan tegangan sistem eksitasi generator tanpa pengendali bersifat tidak kokoh terhadap gangguan, tidak mampu meredam derau pada frekuensi tinggi dan serta mempuyai tanggapan yang lambat terhadap masukan tertentu. Hal ini ditunjukkan oleh nilai puncak maksimum sensitivitas dan nilai puncak maksimunm sensitivitas komplementer yang bernilai besar. Dengan bertambah besarnya kedua nilai puncak maksimum ini menyebabkan batasan minimum margin penguatan dan margin fasa akan semakin kecil.

Untuk pengendali Proporsional (P) diperlihatkan dengan persamaan (9) berikut :

$$
C(s)=0.3539
$$

Untuk hasil simulasi tanggapan tegangan sistem eksitasi generator tanpa dan dengan pengendali Proporsional (P) diperoleh nilai puncak maksimum yang diperlihatkan pada Tabel 4. Berikut :

Tabel 5. Nilai Puncak Maksimum

\begin{tabular}{|l|c|c|}
\hline \multirow{2}{*}{ Parameter } & \multicolumn{2}{|c|}{ Nilai } \\
\cline { 2 - 3 } & $\begin{array}{c}\text { Tanpa } \\
\text { Pengendali }\end{array}$ & $\begin{array}{c}\text { Dengan } \\
\text { Pengendali }\end{array}$ \\
\hline $\begin{array}{l}\text { Nilai Pucak } \\
\text { Sensitivitas }\end{array}$ & 2.9367 & 1.5159 \\
\hline $\begin{array}{l}\text { Nilai Pucak } \\
\begin{array}{l}\text { Sensitivitas } \\
\text { Komplementer }\end{array}\end{array}$ & 2.4776 & 1.0032 \\
\hline
\end{tabular}

Grafik tanggapan fungsi sensitivitas dan fungsi sensitivitas komplementer dari tanggapan tegangan sistem eksitasi generator tanpa dan dengan pengendali Proporsional (P) diperlihatkan pada Gambar 3. Berikut :

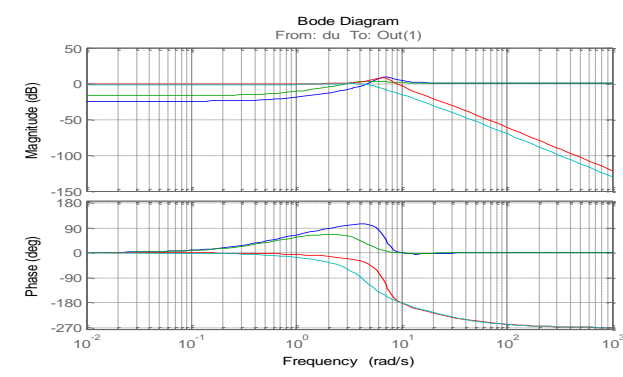

Gambar 5. Tanggapan Fungsi Sensitivitas dan Sensitivitas Komplemeneter

Berdasarkan nilai puncak maksimum ini diperoleh nilai margin penguatan dan nilai margin fasa dari tanggapan tegangan sistem eksitasi generator tanpa dan dengan pengendali Proporsional (P) diperlihatkan pada Tabel 5. Berikut :

Tabel 6. Nilai Margin Penguatan dan Margin Fasa

\begin{tabular}{|l|c|c|}
\hline \multirow{2}{*}{ Parameter } & \multicolumn{2}{|c|}{ Nilai } \\
\cline { 2 - 3 } & $\begin{array}{c}\text { Tanpa } \\
\text { Pengendali }\end{array}$ & $\begin{array}{c}\text { Dengan } \\
\text { Pengendali }\end{array}$ \\
\hline Margin & 1.5164 & 2.9382 \\
\cline { 2 - 3 } Penguatan & $3.6160 \mathrm{~dB}$ & $9.3617 \mathrm{~dB}$ \\
\hline Margin Fasa & $\begin{array}{c}19.6061 \\
\text { derajat }\end{array}$ & $\begin{array}{c}38.5170 \\
\text { derajat }\end{array}$ \\
\hline
\end{tabular}


Untuk pengendali Proporsional Integral (PI) diperlihatkan dengan persamaan (10) berikut :

$$
C(s)=0.2536\left(1+\frac{1}{1.4119 s}\right)
$$

Untuk hasil simulasi tanggapan tegangan sistem eksitasi generator tanpa dan dengan pengendali Proporsional Integral (PI) diperoleh nilai puncak maksimum yang diperlihatkan pada Tabel 6. Berikut :

Tabel 7. Nilai Puncak Maksimum

\begin{tabular}{|l|c|c|}
\hline \multirow{2}{*}{ Parameter } & \multicolumn{2}{|c|}{ Nilai } \\
\cline { 2 - 3 } & $\begin{array}{c}\text { Tanpa } \\
\text { Pengendali }\end{array}$ & $\begin{array}{c}\text { Dengan } \\
\text { Pengendali }\end{array}$ \\
\hline $\begin{array}{l}\text { Nilai Pucak } \\
\text { Sensitivitas }\end{array}$ & 2.9367 & 1.4977 \\
\hline $\begin{array}{l}\text { Nilai Pucak } \\
\text { Sensitivitas } \\
\text { Komplementer }\end{array}$ & 2.4776 & 1.0893 \\
\hline
\end{tabular}

Grafik tanggapan fungsi sensitivitas dan fungsi sensitivitas komplementer dari tanggapan tegangan sistem eksitasi generator tanpa dan dengan pengendali Proporsional Integral (PI) diperlihatkan pada Gambar 4. Berikut :

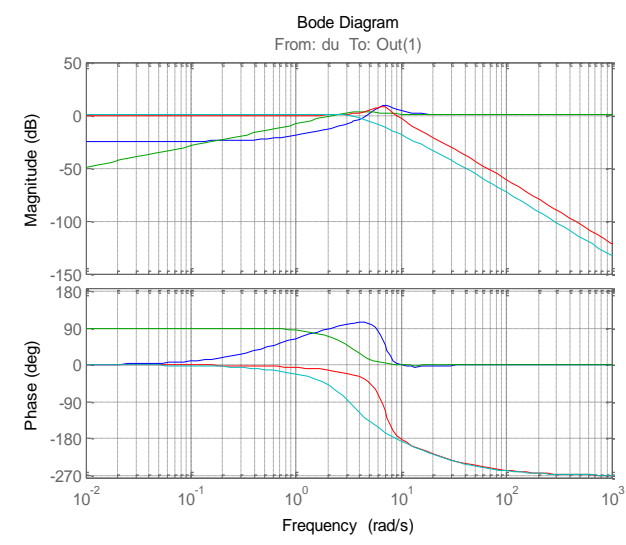

Gambar 6. Tanggapan Fungsi Sensitivitas dan Sensitivitas Komplemeneter

Berdasarkan nilai puncak maksimum ini diperoleh nilai margin penguatan dan nilai margin fasa dari tanggapan tegangan sistem eksitasi generator tanpa dan dengan pengendali Proporsional Integral (PI) diperlihatkan pada Tabel 7. Berikut :
Tabel 8. Nilai Margin Penguatan dan Margin Fasa

\begin{tabular}{|l|c|c|}
\hline \multirow{2}{*}{ Parameter } & \multicolumn{2}{|c|}{ Nilai } \\
\cline { 2 - 3 } & $\begin{array}{c}\text { Tanpa } \\
\text { Pengendali }\end{array}$ & $\begin{array}{c}\text { Dengan } \\
\text { Pengendali }\end{array}$ \\
\hline Margin & 1.5164 & 3.0094 \\
\cline { 2 - 3 } Penguatan & $3.6160 \mathrm{~dB}$ & $9.5695 \mathrm{~dB}$ \\
\hline Margin Fasa & $\begin{array}{c}19.6061 \\
\text { derjat }\end{array}$ & $\begin{array}{c}39.0060 \\
\text { derjat }\end{array}$ \\
\hline
\end{tabular}

Untuk pengendali Proporsional Diferensial (PD) diperlihatkan dengan persamaan (11) berikut :

$$
C(s)=0.9040(1+0.1260 s)
$$

Untuk hasil simulasi tanggapan tegangan sistem eksitasi generator tanpa dan dengan pengendali Proporsional Diferensial (PD) diperoleh nilai puncak maksimum yang diperlihatkan pada Tabel 8. Berikut :

Tabel 9. Nilai Puncak Maksimum

\begin{tabular}{|l|c|c|}
\hline \multirow{2}{*}{ Parameter } & \multicolumn{2}{|c|}{ Nilai } \\
\cline { 2 - 3 } & $\begin{array}{c}\text { Tanpa } \\
\text { Pengendali }\end{array}$ & $\begin{array}{c}\text { Dengan } \\
\text { Pengendali }\end{array}$ \\
\hline $\begin{array}{l}\text { Nilai Pucak } \\
\text { Sensitivitas }\end{array}$ & 2.9367 & 1.3115 \\
\hline $\begin{array}{l}\text { Nilai Pucak } \\
\text { Sensitivitas } \\
\text { Komplementer }\end{array}$ & 2.4776 & 1.0334 \\
\hline
\end{tabular}

Grafik tanggapan fungsi sensitivitas dan fungsi sensitivitas komplementer dari tanggapan tegangan sistem eksitasi generator tanpa dan dengan pengendali Proporsional Diferensial (PD) diperlihatkan pada Gambar 5. Berikut :

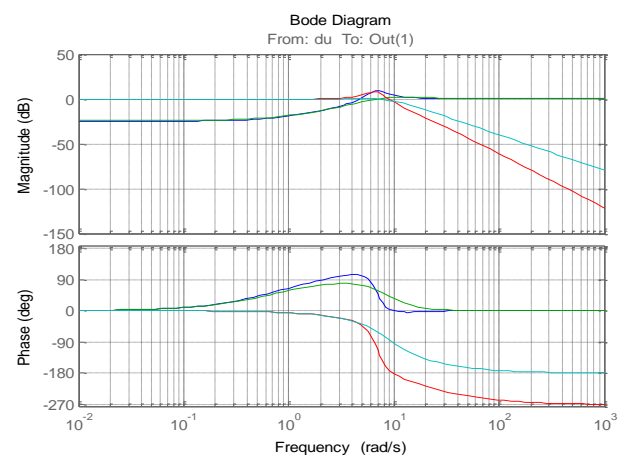

Gambar 7. Tanggapan Fungsi Sensitivitas dan Sensitivitas Komplemeneter 
Berdasarkan nilai puncak maksimum ini diperoleh nilai margin penguatan dan nilai margin fasa dari tanggapan tegangan sistem eksitasi generator tanpa dan dengan pengendali Proporsional Diferensial (PD) diperlihatkan pada Tabel 9. Berikut :

Tabel 10. Nilai Margin Penguatan dan Margin

\begin{tabular}{|l|c|c|}
\hline \multirow{2}{*}{\multicolumn{1}{c|}{ Parameter }} & \multicolumn{2}{c|}{ Fasa } \\
\cline { 2 - 3 } & $\begin{array}{c}\text { Tanpa } \\
\text { Pengendali }\end{array}$ & $\begin{array}{c}\text { Dengan } \\
\text { Pengendali }\end{array}$ \\
\hline Margin & 1.5164 & 4.2105 \\
\cline { 2 - 3 } Penguatan & $3.6160 \mathrm{~dB}$ & $12.4870 \mathrm{~dB}$ \\
\hline Margin Fasa & $\begin{array}{c}19.6061 \\
\text { derjat }\end{array}$ & $\begin{array}{c}44.8220 \\
\text { derjat }\end{array}$ \\
\hline
\end{tabular}

Untuk pengendali Proporsional Integral Diferensial (PID) diperlihatkan dengan persamaan (12) berikut :

$$
\mathrm{C}(\mathrm{s})=1.2285\left(1+\frac{1}{1.0236 \mathrm{~s}}+0.1980 \mathrm{~s}\right)
$$

Untuk hasil simulasi tanggapan tegangan sistem eksitasi generator tanpa dan dengan pengendali Proporsional Integral Diferensial (PID) diperoleh nilai puncak maksimum yang diperlihatkan pada Tabel 10. Berikut :

Tabel 11. Nilai Puncak Maksimum

\begin{tabular}{|l|c|c|}
\hline \multirow{2}{*}{ Parameter } & \multicolumn{2}{|c|}{ Nilai } \\
\cline { 2 - 3 } & $\begin{array}{c}\text { Tanpa } \\
\text { Pengendali }\end{array}$ & $\begin{array}{c}\text { Dengan } \\
\text { Pengendali }\end{array}$ \\
\hline $\begin{array}{l}\text { Nilai Pucak } \\
\text { Sensitivitas }\end{array}$ & 2.9367 & 1.3548 \\
\hline $\begin{array}{l}\text { Nilai Pucak } \\
\text { Sensitivitas } \\
\text { Komplementer }\end{array}$ & 2.4776 & 1.0329 \\
\hline
\end{tabular}

Grafik tanggapan fungsi sensitivitas dan fungsi sensitivitas komplementer dari tanggapan tegangan sistem eksitasi generator tanpa dan dengan pengendali Proporsional Diferensial (PD) diperlihatkan pada Gambar 6. Berikut :

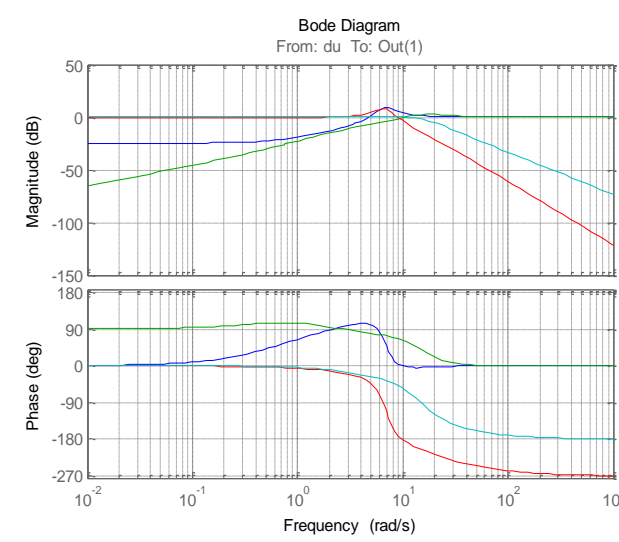

Gambar 8. Tanggapan Fungsi Sensitivitas dan Sensitivitas Komplemeneter

Berdasarkan nilai puncak maksimum ini diperoleh nilai margin penguatan dan nilai margin fasa dari tanggapan tegangan sistem eksitasi generator tanpa dan dengan pengendali Proporsional Integral Diferensial

(PID) diperlihatkan pada Tabel 11. Berikut :

Tabel 12. Nilai Margin Penguatan dan Margin Fasa

\begin{tabular}{|l|c|c|}
\hline \multirow{2}{*}{ Parameter } & \multicolumn{2}{|c|}{ Nilai } \\
\cline { 2 - 3 } & $\begin{array}{c}\text { Tanpa } \\
\text { Pengendali }\end{array}$ & $\begin{array}{c}\text { Dengan } \\
\text { Pengendali }\end{array}$ \\
\hline Margin & 1.5164 & 3.8181 \\
\cline { 2 - 3 } Penguatan & $3.6160 \mathrm{~dB}$ & $11.6370 \mathrm{~dB}$ \\
\hline \multirow{2}{*}{ Margin Fasa } & 19.6061 & 43.3130 \\
& derjat & derjat \\
\hline
\end{tabular}

Untuk pengendali Proporsional Diferensial dengan filter orde pertama pada bagian diferensial (PDF) diperlihatkan dengan persamaan (13) berikut :

$$
C(s)=0.8490\left(1+\frac{0.1350 \mathrm{~s}}{\frac{0.1350}{13.3000} \mathrm{~s}+1}\right)
$$

Untuk hasil simulasi tanggapan tegangan sistem eksitasi generator tanpa dan dengan pengendali Proporsional Diferensial dengan filter orde pertama pada bagian diferensial (PDF) diperoleh nilai puncak maksimum yang diperlihatkan pada Tabel 12. Berikut : 
Tabel 13. Nilai Puncak Maksimum

\begin{tabular}{|l|c|c|}
\hline \multirow{2}{*}{ Parameter } & \multicolumn{2}{|c|}{ Nilai } \\
\cline { 2 - 3 } & $\begin{array}{c}\text { Tanpa } \\
\text { Pengendali }\end{array}$ & $\begin{array}{c}\text { Dengan } \\
\text { Pengendali }\end{array}$ \\
\hline $\begin{array}{l}\text { Nilai Pucak } \\
\text { Sensitivitas }\end{array}$ & 2.9367 & 1.3651 \\
\hline $\begin{array}{l}\text { Nilai Pucak } \\
\begin{array}{l}\text { Sensitivitas } \\
\text { Komplementer }\end{array}\end{array}$ & 2.4776 & 1.0207 \\
\hline
\end{tabular}

Grafik tanggapan fungsi sensitivitas dan fungsi sensitivitas komplementer dari tanggapan tegangan sistem eksitasi generator tanpa dan dengan pengendali Proporsional Diferensial dengan filter orde pertama pada bagian diferensial (PDF) diperlihatkan pada Gambar 7. Berikut :

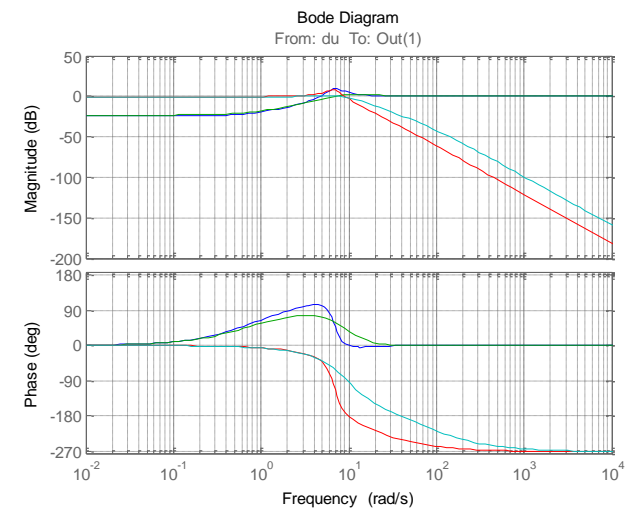

Gambar 9. Tanggapan Fungsi Sensitivitas dan Sensitivitas Komplemeneter

Berdasarkan nilai puncak maksimum ini diperoleh nilai margin penguatan dan nilai margin fasa dari tanggapan tegangan sistem eksitasi generator tanpa dan dengan pengendali Proporsional Diferensial dengan filter orde pertama pada bagian diferensial (PDF) diperlihatkan pada Tabel 13. Berikut:

Tabel 14. Nilai Margin Penguatan dan Margin Fasa

\begin{tabular}{|l|c|c|}
\hline \multirow{2}{*}{ Parameter } & \multicolumn{2}{|c|}{ Nilai } \\
\cline { 2 - 3 } & $\begin{array}{c}\text { Tanpa } \\
\text { Pengendali }\end{array}$ & $\begin{array}{c}\text { Dengan } \\
\text { Pengendali }\end{array}$ \\
\hline $\begin{array}{l}\text { Margin } \\
\text { Penguatan }\end{array}$ & 1.5164 & 3.7390 \\
\cline { 2 - 3 } Margin Fasa & $\begin{array}{c}3.6160 \mathrm{~dB} \\
19.6061 \\
\text { derjat }\end{array}$ & $\begin{array}{c}42.4550 \mathrm{~dB} \\
\text { derjat }\end{array}$ \\
\hline
\end{tabular}

Untuk pengendali Proporsional Integral Diferensial dengan filter orde pertama pada bagian diferensial (PIDF) diperlihatkan dengan persamaan (14) berikut :

$$
C(s)=0.8455\left(1+\frac{1}{1.6697 \mathrm{~s}}+\frac{0.1487 \mathrm{~s}}{\frac{0.1487}{10.8875} \mathrm{~s}+1}\right)
$$

Untuk hasil simulasi tanggapan tegangan sistem eksitasi generator tanpa dan dengan pengendali Proporsional Integral Diferensial dengan filter orde pertama pada bagian diferensial (PIDF) diperoleh nilai puncak maksimum yang diperlihatkan pada Tabel 14 . Berikut :

Tabel 15. Nilai Puncak Maksimum

\begin{tabular}{|l|c|c|}
\hline \multirow{2}{*}{ Parameter } & \multicolumn{2}{|c|}{ Nilai } \\
\cline { 2 - 3 } & $\begin{array}{c}\text { Tanpa } \\
\text { Pengendali }\end{array}$ & $\begin{array}{c}\text { Dengan } \\
\text { Pengendali }\end{array}$ \\
\hline $\begin{array}{l}\text { Nilai Pucak } \\
\text { Sensitivitas }\end{array}$ & 2.9367 & 1.3928 \\
\hline $\begin{array}{l}\text { Nilai Pucak } \\
\text { Sensitivitas } \\
\text { Komplementer }\end{array}$ & 2.4776 & 1.0441 \\
\hline
\end{tabular}

Grafik tanggapan fungsi sensitivitas dan fungsi sensitivitas komplementer dari tanggapan tegangan sistem eksitasi generator tanpa dan dengan pengendali Proporsional Integral Diferensial dengan filter orde pertama pada bagian diferensial (PIDF) diperlihatkan pada Gambar 8. Berikut :

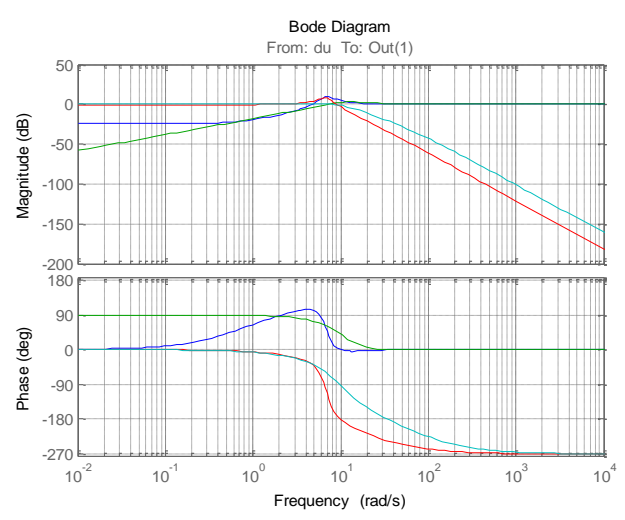

Gambar 10. Tanggapan Fungsi Sensitivitas dan Sensitivitas Komplemeneter 
Berdasarkan nilai puncak maksimum ini diperoleh nilai margin penguatan dan nilai margin fasa dari tanggapan tegangan sistem eksitasi generator tanpa dan dengan pengendali Proporsional Integral Diferensial dengan filter orde pertama pada bagian diferensial (PIDF) diperlihatkan pada Tabel 15. Berikut :

Tabel 16. Nilai Margin Penguatan dan Margin Fasa

\begin{tabular}{|l|c|c|}
\hline \multirow{2}{*}{ Parameter } & \multicolumn{2}{|c|}{ Nilai } \\
\cline { 2 - 3 } & $\begin{array}{c}\text { Tanpa } \\
\text { Pengendali }\end{array}$ & $\begin{array}{c}\text { Dengan } \\
\text { Pengendali }\end{array}$ \\
\hline Margin & 1.5164 & 3.5458 \\
\cline { 2 - 3 } Penguatan & $3.6160 \mathrm{~dB}$ & $10.9940 \mathrm{~dB}$ \\
\hline Margin Fasa & $\begin{array}{c}19.6061 \\
\text { derjat }\end{array}$ & $\begin{array}{c}42.0760 \\
\text { derjat }\end{array}$ \\
\hline
\end{tabular}

Berdasarkan hasil simulasi yang diperlihatkan pada Tabel 4. s/d Tabel 15. Terlihat bahwa tanggapan tegangan sistem eksitasi generator untuk semua pengendali bersifat kokoh terhadap gangguan, mampu meredam derau pada frekuensi tinggi dan tanggapan yang cepat terhadap masukan tertentu. Hal ini dibuktikan untuk pengendali Proporsional (P) diperoleh nilai puncak sensitvitas sebesar 1.5159 dan nilai puncak sensitivitas komplementer sebesar 1.0032 . Untuk batasan minimum margin penguatan sebesar $9.3617 \mathrm{~dB}$ dan batasan minimum margin fasa sebesar 38.5170 derjat. Untuk pengendali Proporsional Integral (PI) diperoleh nilai puncak sensitvitas sebesar 1.4977 dan nilai puncak sensitivitas komplementer sebesar 1.0893 . Untuk batasan minimum margin penguatan sebesar $9.5695 \mathrm{~dB}$ dan batasan minimum margin fasa sebesar 38.0060 derjat. Untuk pengendali Proporsional Diferensial (PD) diperoleh nilai puncak sensitvitas sebesar 1.3115 dan nilai puncak sensitivitas komplementer sebesar 1.0334. Untuk batasan minimum margin penguatan sebesar $12.4870 \mathrm{~dB}$ dan batasan minimum margin fasa sebesar 44.8220 derjat. Untuk pengendali Proporsional Integral Diferensial (PID) diperoleh nilai puncak sensitvitas sebesar 1.3548 dan nilai puncak sensitivitas komplementer sebesar 1.0329. Untuk batasan minimum margin penguatan sebesar $11.6370 \mathrm{~dB}$ dan batasan minimum margin fasa sebesar 43.3130 derjat. Untuk Proporsional Diferensial dengan filter orde pertama pada bagian diferensial (PDF) diperoleh nilai puncak sensitvitas sebesar 1.3651 dan nilai puncak sensitivitas komplementer sebesar 1.0270. Untuk batasan minimum margin penguatan sebesar $11.4550 \mathrm{~dB}$ dan batasan minimum margin fasa sebesar 42.9720 derjat. Untuk Proporsional Integral Diferensial dengan filter orde pertama pada bagian diferensial (PIDF) diperoleh nilai puncak sensitvitas sebesar 1.3928 dan nilai puncak sensitivitas komplementer sebesar 1.0441. Untuk batasan minimum margin penguatan sebesar $10.9940 \mathrm{~dB}$ dan batasan minimum margin fasa sebesar 42.0760 derjat.

\section{KESIMPULAN}

Adapun kesimpulan dari penelitian ini adalah tanggapan tegangan sistem eksitasi generator dengan berbagai pengendali bersifat kokoh terhadap gangguan, mampu meredam derau pada frekuensi tinggi dan mempuyai tanggapan yang cepat terhadap masukan tertentu. Hal ini dibuktikan dengan nilai puncak sensitivitas yang kecil dari 2.0000 dan nilai puncak sensitivitas komplementer yang kecil dari 1.2500, batasan minimum dari margin penguatan besar dari $6.0000 \mathrm{~dB}$ dan batasan minimum dari margin fasa antara 30.0000 derjat s/d 60.0000 derjat untuk setiap pengendali.

\section{DAFTAR PUSTAKA}

[1] Graham, R., 1999. Power System Oscillations. Massachusetts: Kluwer Academic Publisher.

[2] Skogestad, S. \& Postlethwaite, I., 1996. Multivariable Feedback Control Analysis and Design. New York : McGraw Hill.

[3] Eremia, M., \& Shahidehpour, M, 2013. Handbook of Electrical Power System Dynamics . New Jersey: Wiley.

[4] Laksono, H. D., Revan , M. \& Rabiarahim , A., 2014. Pemodelan dan Analisa Sistem Eksitasi Generator. Teknika, 21(01).

[5] Laksono, H. D. \& Revan , M., 2014. Perancangan dan Analisa Kendali Sistem Eksitasi Generator Tipe Arus Searah Dengan PIDTool Model Paralel. Teknika , 21(3). 
[6] Laksono, H. D. \& Yulianto, N. F., 2013. Evaluasi Pola Tingkah Laku Tegangan Sistem Eksitasi Generator Dengan Metoda Penempatan Kutub Menggunakan Algoritma Bass - Gura. Jurnal Nasional Teknik Elektro , 02(02).

[7] Laksono, H. D. \& Yulianto, N. F., 2013. Evaluasi Kestabilan dan Kekokohan Tanggapan Tegangan Sistem Eksitasi Generator Dengan Metoda Penempatan Kutub Menggunakan Algoritma Ackerman - Gura. Konferensi Nasional $\mathrm{Ke}-7$ Forum Pendidikan Tinggi Teknik Elektro Indonesia (FORTEI), Padang 26 28 September 2013

[8] Laksono, H. D. \& Rezki, S. O., 2012. Penerapan Sistem Kendali Kokoh Dengan Metoda H Pada Sistem Eksitasi Generator. Amplifier, 02(02).

[9] Karnoto, M. Facta \& Aris T,2000. Perbandingan Pengaruh Sistem Eksitasi Konvensional dan Non Konvensional Terhadap Kestabilan Generator Untuk Meningkatkan Keandalan Sistem Kelistrikan, Proceedings, Seminar Sistem Tenaga Elektric I, Insitute Teknologi Bandung.

[10] Saadat, H., 1999. Power System Analysis. Canada: McGraw Hill.

[11] Laksono, H. D., 2015. Sistem Kendali. Jogjakarta PIDTool Matlab Model Standard : Andalas Press.

\section{Biodata Penulis}

Heru Dibyo Laksono ST, MT, Menyelesaikan S1 di Jurusan Teknik Elektro Universitas Andalas (Unand) Padang tahun 2000 bidang Teknik Tenaga Listrik. Pendidikan S2 bidang Kendali dan Sistem diselesaikan di Institute Teknologi Bandung (ITB) tahun 2004. Masuk sebagai dosen Teknik Elektro Universitas Andalas sejak tahun 2005.

Aidil Danas ST, MT, Menyelesaikan S1 di Jurusan Teknik Elektro Universitas Ekasakti (Unes) Padang tahun 1997 bidang Teknik Tenaga Listrik. Pendidikan S2 bidang Kendali Sistem Tenaga diselesaikan di Universitas Andalas tahun 2013. Masuk sebagai dosen Teknik Elektro Universitas Andalas sejak tahun 1998.
Doohan Haliman, ST, Terdaftar sebagai mahasiswa jurusan Teknik Elektro Fakultas Teknik Universitas Andalas pada tahun 2010 dengan bidang keahlian sistem tenaga listrik.

Wayu Diafridho A, ST, Terdaftar sebagai mahasiswa jurusan Teknik Elektro Fakultas Teknik Universitas Andalas pada tahun 2009. dengan bidang keahlian sistem tenaga listrik. Saat ini bekerja sebagai karyawan PT. PLN (Persero) Area Padang Sidempuan Sumatera Utara. 